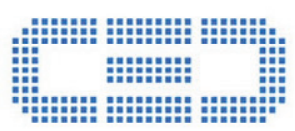

Centre d'Estudis Demogràfics

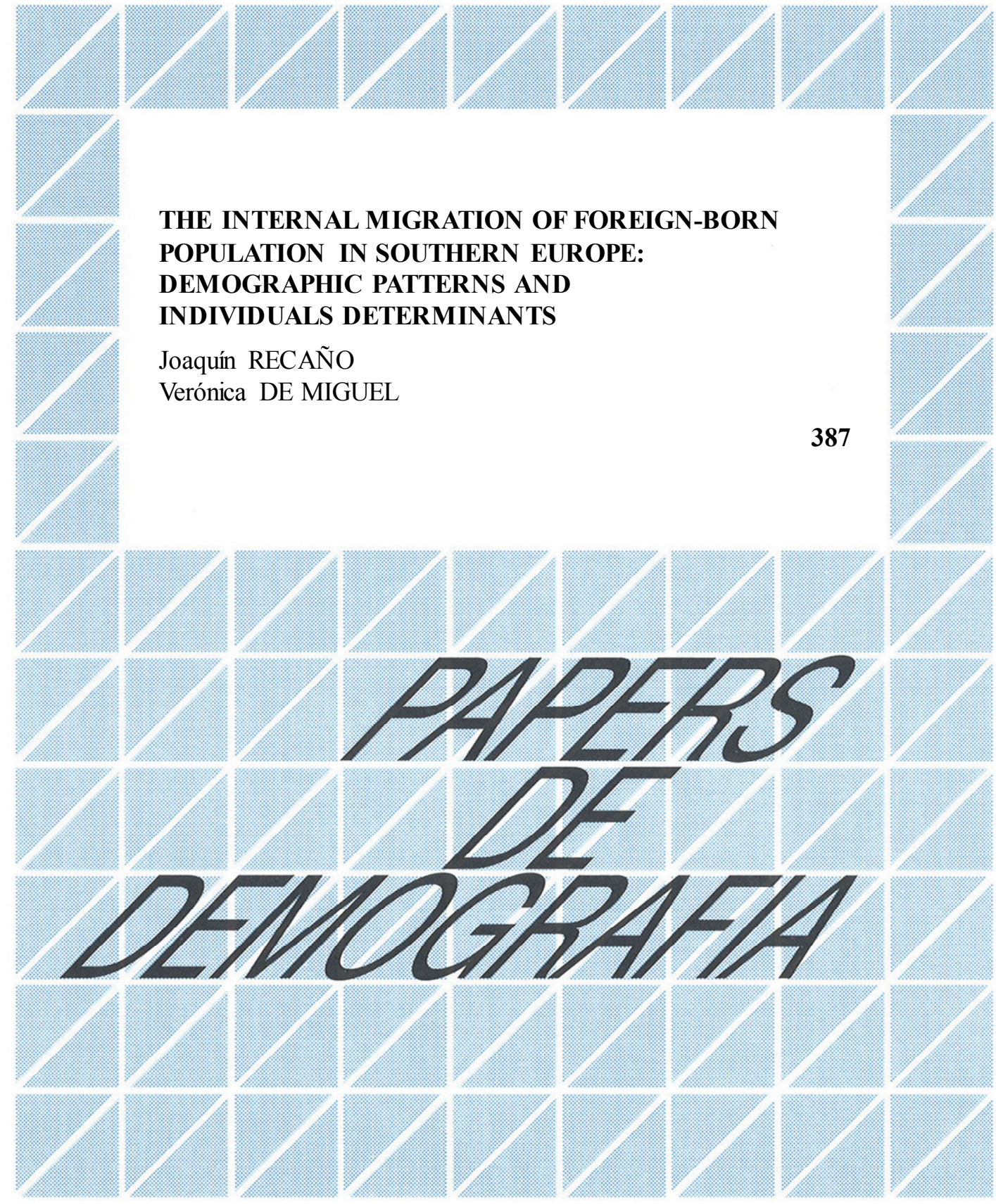




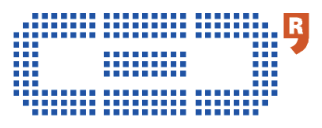

Centre d'Estudis Demogràfics

THE INTERNAL MIGRATION OF FOREIGN-BORN

POPULATION IN SOUTHERN EUROPE:

DEMOGRAPHIC PATTERNS AND

INDIVIDUALS DETERMINANTS

Joaquín RECAÑO

Verónica DE MIGUEL

Una versió del document es publicarà com a capítol de llibre a:

FINNEY, Nissa; CATNEY, Gemma (Eds.).

Minority Internal Migration in Europe.

Aldershot: Ashgate Publishing.

Centre d'Estudis Demogràfics 
Resum.- La migració interna de la població nascuda a l'estranger, en el sud d'Europa: patrons demogràfics i determinants individuals

Es descriuen els diferents factors sociodemogràfics i determinants individuals que expliquen els patrons de migració interna de la població nascuda a l'estranger, en alguns països del sud d'Europa: Itàlia, Portugal i Espanya, països amb una història comuna d'emigració i que s'han convertit, des de mitjans dels anys noranta del segle XX, en destinacions d'immigració. L'anàlisi es basa en microdades de les persones que han canviat el seu lloc de residència, amb informació demogràfica (edat, sexe i país de naixement, origen i destinació de la migració interna, tinença de l'habitatge, ocupació i nivell d'instrucció). Es respon a: el perfil demogràfic dels nascuts a l'estranger que protagonitzen migracions internes, són similars al dels nadius, per edat i sexe? Aquests patrons de migració es diferencien segons origen de l'immigrant? Són els patrons demogràfics observats sempre iguals, segons grups nacionals o bé es diferencien segons el país de destinació? I finalment, con influeixen els determinants individuals sobre la migració interna dels estrangers, en comparar per país de residència?

Després d'una anàlisi descriptiva dels patrons demogràfics de la migració interna dels nascuts a l'estranger i els nascuts en el país, s'apliquen algunes regressions logístiques per explorar algunes de les característiques individuals i agregades, que poden explicar les diferències en la mobilitat entre els grups i entre els països del sud d'Europa. Les principals conclusions són: la intensitat de la migració interna de la població nascuda a l'estranger és molt superior a la de la població nativa (això es demostra entre els africans, asiàtics i llatinoamericans); els dos primers grups també mostren importants diferències de gènere (els homes es mouen més), però els patrons són més equilibrats per als llatinoamericans; i finalment, els factors individuals tenen influències semblants en tots els països analitzats, fins $\mathrm{i}$ tot en aquells a on l'odds-ratio mostra diferències més grans pels de distància migratòria mitjana i llarga.

Paraules clau.- Migració internacional, migració interna, població nascuda a l'estranger, dades censals, comparativa entre països.

Resumen.- La migración interna de la población nacida en el extranjero, en el sur de Europa: los patrones demográficos y los determinantes individuales

Se describen los diferentes factores sociodemográficos y los determinantes individuales que explican los patrones de migración interna de la población nacida en el extranjero, en algunos países del sur de Europa: Italia, Portugal y España, países con una historia común de emigración y que se han convertido, desde mediados de los años noventa del siglo XX, en destinos de inmigración. El análisis se basa en microdatos de las personas que han cambiado su lugar de residencia, con información demográfica (edad, sexo y país de nacimiento, origen y destino de la migración interna, la tenencia de la vivienda, el empleo y el nivel de instrucción). Se responde a: ¿el perfil demográfico de los nacidos en el extranjero, que protagonizan migraciones internas, son similares a la de los nativos, por edad y sexo? ¿Estos patrones de migración, se diferencian según origen del inmigrante? ¿Son los patrones demográficos observados siempre igual según grupos nacionales o bien se diferencian según el país de destino? Y por último, ¿cómo influyen los determinantes individuales sobre la migración interna de los extranjeros, en comparar por país de residencia? 
Tras un análisis descriptivo de los patrones demográficos de la migración interna de los nacidos en el extranjero y de los nacidos en el país, se aplican algunas regresiones logísticas para explorar algunas de las características individuales y agregadas, que pueden explicar las diferencias en la movilidad entre los grupos y entre los países del sur de Europa. Las principales conclusiones son: la intensidad de la migración interna de la población nacida en el extranjero es muy superior a la de la población nativa (esto se demuestra entre los africanos, asiáticos y latinoamericanos); los dos primeros grupos también muestran importantes diferencias de género (los hombres se mueven más) pero los patrones son más equilibrados para los latinoamericanos; y por último, los factores individuales tienen influencias similares en todos los países analizados, incluso en aquellos donde el odds-ratio muestra diferencias mayores para los de media y larga distancia migratoria.

Palabras clave.- Migración internacional, migración interna, población nacida en el extranjero, datos censales, comparativa entre países.

\section{Abstract.- The internal migration of foreign-born population in Southern Europe: demographic patterns and individuals determinants}

The main objective of this document is to describe the different socio-demographical and individual factors that explain the internal migration patterns of the foreign-born population in some Southern European countries: Italy, Portugal and Spain, countries with a common history of past emigration and that have become dynamic destinations in the European context of immigration since de middle of the nineties of the XXth century. The analysis is based on micro-data files which provide information on individuals that have changed their place of residence by basic demographic characteristics (age, sex and country of birth, origin and destination of internal migration, housing tenure, employment and level of education). We intend to answer the following questions: Are the demographic patterns of internal migration of foreign-born similar to those of natives by age and sex? Do these migration patterns differ by immigrant origin? Are the observed demographic patterns by specific national groups always the same or do they differ according to the country of destination? And lastly, what are the effects of the individual characteristics on the internal migration of foreigners as we compare by country of residence? Following a descriptive analysis of demographic patterns of internal migration of foreign-born and native-born we will apply some logistic regression to explore some of the individual and aggregated characteristics that may influence in explaining differences in mobility among groups and countries in Southern Europe. Our main findings are: the internal migration intensity of the foreign born population is considerably higher than that of native population (this is proved for Africans, Asians and Latin-Americans); the first two groups also show important gender differences (males are more mobile), but patterns are more balanced for Latin-Americans; and finally, individual factors have similar influences in all the considered countries, even if the odds-rations show higher differences for medium and long distance migration.

Keywords.- International migration, internal migration, foreign-born population, Census data, cross-country comparison. 


\section{INDEX}

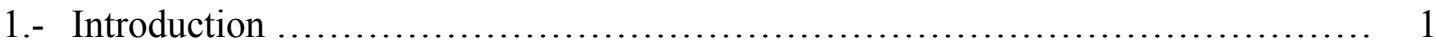

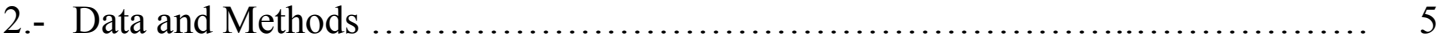

3.- The context of international immigration in Italy, Portugal and Spain ............. 11

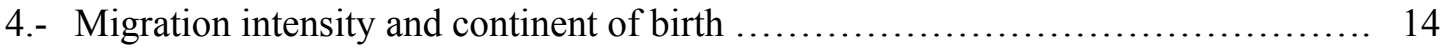

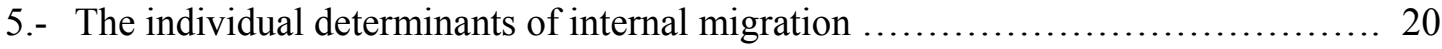

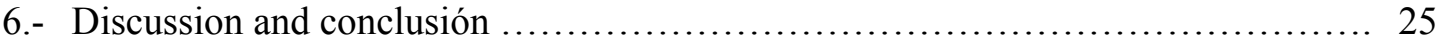

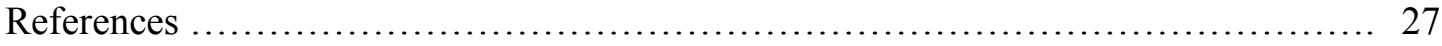

\section{LIST OF TABLES}

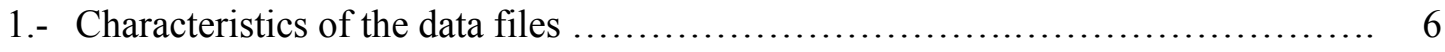

2.- Incidence of migration by main individual characteristics. People aged 25 and

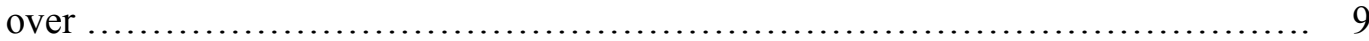

3.- Stocks and inflows of foreign population by year and country of residence in

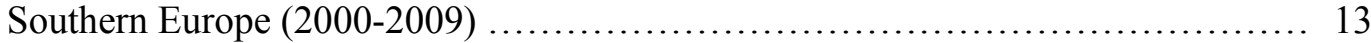

4.- Sex-ratio and geographical origin of immigrants in Southern Europe (2001) ........ 13

5.- Demographic indicators by type of migration and continent of birth (2000-2001) ... 18

6.- Odds ratios for migrating by type of migration .............................. 21

\section{FIGURE INDEX}

1.- Questions about migration in the Italian, Portuguese and Spanish Censuses of 2001

2.- Standardized age rates of internal migration of Southern Europe by sex, age and

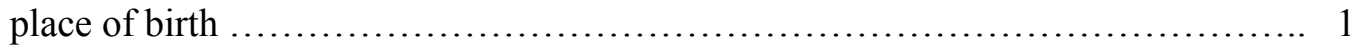

3.- Internal migration rates by sex, age and continent of birth $\ldots \ldots \ldots \ldots \ldots \ldots \ldots \ldots \ldots \ldots \ldots$ 


\title{
THE INTERNAL MIGRATION OF FOREIGN-BORN POPULATION IN SOUTHERN EUROPE: DEMOGRAPHIC PATTERNS AND INDIVIDUALS DETERMINANTS ${ }^{1}$
}

\author{
Joaquín RECAÑO \\ jrecano@ced.uab.es \\ Verónica DE MIGUEL \\ vdmiguel@uma.es
}

\section{1.- Introduction}

The massive arrival of foreign immigrants since the nineties of the XXth century constitutes a transcendental geo-demographic and social phenomenon in Italy, Portugal and Spain. These countries, with a common emigration experience in past, have lived a fast transition from the eighties of last century that has turned them into some of the most important immigration destinations in the European Union. These Southern Europeans countries hosted more than 10.4 million foreigners in January 2009, dramatically increasing the amount of less than 2.9 in 2000. Immigration has therefore faced a rapid and accelerated growth: with an inflow of 618,300 foreigners in 2000 to a maximum of $1,205,500$ in $2007^{2}$ (OECD, 2011). In this intense process, Italy, Portugal and Spain share a series of common characteristics: intensification and acceleration of the flows,

\footnotetext{
${ }^{1}$ This paper has been carried out in the framework of two research projects: La movilidad geográfica de la población extranjera en España: factores sociodemográficos y territoriales (SEJ2007-61662/GEOG) and Inflexión del ciclo económico y transformaciones de las migraciones en España (CSO2010-19177), both funded by the Ministry of Education and Science, National R+D+I Plan 2004-2007 and 2007-2010.

Acknowledgements: We would like to acknowledge the help of the Editors (Nissa Finney and Gemma Catney) who provided insightful comments and suggestions for improvement.

2 Spain, for instance, was the main destination of the European Union for the foreign migratory flows between 2004 and 2008, and became one of the three countries that attracted more than the 30 per cent of the
} 
diversification in the demographic structure by age, sex and geographical origin and a rising quantitative importance of the irregular flows (Domingo and Gil-Alonso 2007; Recaño-Valverde and Domingo 2006).

Three groups of factors that help to explain the immigration in Southern Europe can be identified (King and Zontini 2000). First one related to geography, the countries in this area are located in the routes of access to other destinations for the people crossing the South Mediterranean border and the people crossing the Eastern European border (Italy). During the sixties and the seventies of the previous century, Spain and Italy played the role of transitional countries for the emigrants moving from the North of Africa whose main final destinations were France, Switzerland, Germany, Belgium and The Netherlands. But besides this fact, Italy, Portugal and Spain have also maintained a historical border with Latin-America due to their cultural and idiomatic relationships (Spain and Portugal), together with a past of strong migratory exchanges that includes Italy. The second factor corresponds to the economical motivations, the modernization of the economy and the growing relevance of some specific productive sectors. Since the nineties of the XXth century, Spain, Portugal (Corkill 2001) and Italy have begun to experiment a phenomenon that already occurred in the Northern Europe three or four decades before: a rising prosperity, which was associated in Spain and Portugal to their entry in the European Union in 1986 and an accelerated process of population aging that implied the opening of a professional sector around personal services. Besides, the shortage of workers in certain low paid services in sectors such as tourism, hotel industry, agriculture and construction has activated a great global demand of non-qualified labourers.

The third group of reasons corresponds to the socio-demographic factors that King and Zontini (2000) called the border demographic gradient: that is to say, the situation of progressive aging in these reception countries with a very low fertility as compared to the full cohorts from the South of the Mediterranean and other Latin-American origins.

The impact of these numerous arrivals has been deeply noticed in all spheres of these countries. The modification of the internal migration patterns is one of the many consequences that stem from this phenomenon. However, this topic has originated limited interest in the new destinations of this immigration, in contrast with the situation in the

inflows in the UE-25 + Norway, Switzerland for the period 2000-2009 (see table A.1.1. Inflows of foreign population into selected OECD countries and the Russian Federation in www.oecd.org/migration/imo) 
Western countries with longer tradition on external immigration, such as the United States, Canada or Great Britain. In these latter countries the research on the internal migration patterns of the foreign or foreign-born populations has given rise to abundant literature mainly from the late eighties.

In this chapter we are going to present some results of our research, for which we have focused our efforts on answering the following questions: Are the demographic patterns of internal migration of foreigners similar to those of natives by age and sex? Do these migration patterns differ by country of origin? Are the observed demographic patterns by specific national groups always the same or do they vary according to the country of destination? And lastly, what are the effects of the individual characteristics on the internal migration of foreigners as we compare by country of residence?

In brief, the objective is to study which demographic characteristics and individual factors take part in explaining the internal mobility when we consider the behaviour of the nativeborn population as the comparative element.

Up to now, the studies carried out in Canada, the United States, Germany, Belgium and Great Britain have arrived to the following conclusions: immigrants ${ }^{3}$ tend to be more mobile than natives because of their demographic and social characteristics, like their age and their life cycle stage when they entry the destination country, the duration of residence, the situation of the labour market and their academic attainment (Bartel 1989; Bartel and Koch 1991; Nogle 1994). On the other hand, several authors have pointed out that foreignborn people show lower elasticity than native-born population to adapt to the factors of the regional market ${ }^{4}$ that have a stronger incidence on the medium and long distance changes of residence, such as the unemployment levels, the salary differentials and the areas with higher employment growth (Liaw and Frey 1998; Kritz and Nogle 1994; Nogle 1994). A highlighted result defends that social networks have an intense influence on the mobility of these collectives: the presence and territorial location of already existing communities of the same immigrant origin lessen the costs associated with the migration process. These

\footnotetext{
${ }^{3}$ We define immigrant for this chapter as a person born in another country (foreign-born). The reasons underlying this decision are based on the fact that some countries do not provide information by both approaches: country of birth and country of citizenship. Furthermore, this is a characteristic that remains unchanged with time.

${ }^{4}$ These results, however, have been obtained in countries with high mobility, where native-born population shows an intense migration response to the economic incentives, both at the individual and regional levels. We advance that the situation in the Mediterranean countries (Spain and Italy) is not the same.
} 
communities represent the immigrants' main source of information about the potential internal destinations (Frey 1995; Gurak and Kritz 2000). The concentration of the natives of a particular community in a specific region also constitutes an element of attraction for those of the same geographical origin. By integrating the effect of the contextual economic factors and the action of the social networks Gurak and Kritz (1998) show that immigrants move less frequently from regions with high economic growth rates, with high proportions of workers in the manufacture sector and with high concentrations of immigrants from the same national origin. Attending to these arguments, the concentration of nationals from a same country in a region acts, thus, as a break of the internal migration of these collectives. Newbold (1996) has stressed, in his work about Canada, the capacity of some regions to attract and keep foreign immigrants from other Canadian regions, result which is confirmed by the recent research by Krahn and Derwing (2005).

Why do we study these three countries? There are several considerations to be regarded in this respect. First of all, we find the absence of comparative studies about the foreign population or foreign born population mobility in the academic literature: the existent works at present are mainly focused on national contexts. The second reason is the structural comparability of the three countries that constitute our object of analysis in different aspects. They have a common international migration dynamic, with an intense emigratory past that has turned at present to a situation of intense immigration. They receive flows which are very divers in terms of origin composition, and they are also countries with a moderated or low internal mobility (Rees and Kupiszewski 1999; Módenes 2002), in which the incorporation of the foreign population has meant the increase of this internal migration mobility (Recaño-Valverde and Roig 2006; Mocetti and Porello, 2010). Finally, they have very similar demographic and labour structures. These facts make these Southern European countries interesting laboratories to assess the effects of the foreign born population internal migration in geographical contexts of low mobility.

In Spain and Italy, the developed researches show some similarities with the results highlighted by previous international literature about other destinations (Recaño-Valverde 2003; Recaño-Valverde and Roig 2006; Mocetti and Porello 2010). However, these are countries with low internal migration intensity, where the differences in mobility between foreign-born and native-born populations are more noticeable than in countries with higher internal mobility, such as the United States and Canada. Altogether, international researchers have collected a series of socio-demographic and economic variables that have 
a decisive impact on the foreign or foreign-born population mobility. For this work, we will tackle some of these aspects from a more comparative perspective. To achieve this objective, we will assess the demographic structure, the migratory intensity and the individual factors that have an influence on the mobility of the different foreign-born groups in some Southern European countries.

\section{2.- Data and methods}

At present, the available data for the study of the internal migration of the foreign population or non-native born population differ considerably for the different countries that have been included in this work. In this regard, Spain and Italy count on population registers, the Padrón Continuo for Spain and the Anagrafe dei Comuni italiani for Italy ${ }^{5}$, which provide data on migratory flows up to a municipality level. In Portugal, internal migration data is limited to those provided by the decennial censuses ${ }^{6}$. In the Spanish case, the information about migration is derived from the flows that the Statistics on Residential Variations (Estadísticas de Variaciones Residenciales - EVR) establish according to the data received from the population register (Padrón Continuo). One registration in a municipality implies an automatic dropped out of the same person in the register of the previous municipality of residence. In the Italian case, the information about origin and destination of the migration movement is obtained through the iscrizioni (registration) and cancellazioni (cancellation) because of the trasferimento di residenza (change of residence), in a very similar way to that described for Spain. However, there exist some essential differences between both sources despite being population registers. The Italian data are just referred to the population with a certain legal status of residence, who are the only ones allowed to be registered. On the other hand, the Spanish Continuous Register

\footnotetext{
5 A detailed description of the characteristics of the Italian data on internal migration can be found at: http://demo.istat.it/bil2006/index03.html; with regards to the Spanish data, the migratory information is elaborated in the Statistics of Residential Variations (EVR) that comes from the population register (Padrón Continuo) (see http://www.ine.es/daco/daco42/migracion/notaevr.htm). The Italian data about mobility provide information about the academic attainment, the marital status or occupation, which cannot be found at the Spanish EVR.

6 The demographic profile of the foreign population at a local level that asked for the resident status can be checked at http://www.ine.pt/xportal/xmain?xpid=INE\&xpgid=ine_base_dados, but no other migratory information can be found. Similar information about population with a legal residential status is provided by
} 
(Padrón Continuo) includes both immigrants with legal status of residence and immigrants in an irregular situation (with no residence or work permits). The scope of the Spanish population register is, thus, higher than the Italian, as we refer to foreign born population, allowing gathering information by country of birth and country of citizenship, which is restricted to the latter in the Italian register. As we have already pointed out, the variations in the characteristics of the Spanish and the Italian information, and the absence of some of it in the Portuguese case, take us to reject data on flows and just consider some homogeneous information that is available for the three countries. This is the reason why we have decided to use the 2011 Census information.

Nonetheless, it is difficult to compare Census data for different countries (Courgeau, 1973a and 1973b; Long and Boertlein, 1990; Bell, Blake et al, 2002; Bell and Rees, 2006; Bell and Muhidin, 2009). Realities of each context, geographical divisions, priorities of the specific administrations and years of collection change, thus research questions and hypothesis to be tested have to be adapted to these disparities ${ }^{7}$. However, our effort to homogenize the data sets has been facilitated to a great extent by the Integrated Public Use of International Microdata Series (IPUMS) (Minnesota Population Centre 2009), which has provided us with the harmonized data files for the countries we have included in the analysis for this chapter (Table 1).

Table 1.- Characteristics of the data files

\begin{tabular}{|c|c|c|c|c|c|c|c|}
\hline Country & $\begin{array}{c}\text { Sample } \\
\text { fraction } \\
\text { (\%) }\end{array}$ & $\begin{array}{c}\text { Sample } \\
\text { size }\end{array}$ & $\begin{array}{c}\text { Foreign-born } \\
\text { population } \\
\text { subsample }\end{array}$ & $\begin{array}{c}\text { Foreign } \\
\text { population } \\
\text { subsample }\end{array}$ & $\begin{array}{c}\text { Minor } \\
\text { census date } \\
\text { (d-m-yr) }\end{array}$ & $\begin{array}{c}\text { Major } \\
\text { administrative } \\
\text { unit }\end{array}$ & $\begin{array}{c}\text { administrative } \\
\text { unit }\end{array}$ \\
\hline Italy & 5 & $2,990,739$ & $117,890(3.9 \%)$ & $70,462(2.4 \%)$ & $21 / 10 / 2001$ & Region (20) & Municipality(8101) \\
Portugal & 5 & 517,026 & $32,136(6.2 \%)$ & $11,440(2.2 \%)$ & $12 / 03 / 2001$ & Subregion (22) & Municipality(308) \\
Spain & 5 & $2,039,274$ & $107,394(5.3 \%)$ & $77,631(3.8 \%)$ & $01 / 11 / 2001$ & Province (52) & Municipality(8111) \\
\hline
\end{tabular}

Source: Own elaboration based on the Integrated Public Use of International Microdata Series: version 5.0. Minneapolis: University of Minnesota, 2009

the Italian municipalities for the data base of the ISTAT. However, those data are not available in Spain for the municipal level, although it is for the provincial level.

${ }^{7}$ Apart from the differences in the socieconomical and demographical contexts, definitions on migration are much affected by the particularities of the spatial administrative division and the time intervals used in the census to obtain the category of migrants. 
The microdata of the census data base of IPUMS allows us to obtain two samples: one with data about the population born abroad and one with the population by citizenship. We have chosen to analyse the sample by country/place of birth. Two are the motivations that explain this option. First of them, the characteristic of place of birth remains stable across time in contrast to the numerous acquisitions of citizenship by the population of LatinAmerican origin that are registered in the three considered countries. The second, which is indirectly linked to the previous one, is determined by the higher volume of the sample (Table 1). The major inconvenience of this decision is the fact that a great deal of the foreign born population, especially in other European countries, corresponds to the children of Portuguese, Spanish or Italian parents born abroad during the intense emigration processes of these countries in the sixties and seventies. We argue that this factor does not alter the sense of the results.

Regarding our specific research objectives, we also have to mention the approaches followed in the different countries with regards to the questions on mobility. In Italy and Portugal the census inquired about the place of residence one year ago ${ }^{8}$. For Spain, we have information about the last place of residence and the year of change of residence so, even if conceptually it is not exactly the same, we can still build up a proxy for the dependent variable that can be understood as the situation one year ago, like in the other mentioned countries (Figure 1).

On the other hand, we have had to adjust our explanatory variables to the degree of detail supplied by each census, while maintaining the possibilities of cross-national comparisons. This has leaded us to a greater simplicity in the categorization of the covariates that we would have used for country specific models. Since educational attainment was not coded in the same way, we have re-coded it in such a way that it allows comparison (for the recodification we have previously studied the intra-variation with regards to our dependent variables). The most difficult explanatory variable to harmonize has been that referred to the place of birth. First of all, not all countries include detailed information on this ${ }^{9}$. Secondly, those that do provide some sort of detail about geographical origin, emphasize

\footnotetext{
${ }^{8}$ In Portugal information was also collected about the place of residence five years ago. Since the similarity between migrants and migration movements is higher for short periods, we have kept the year interval as that of our interest.

${ }^{9}$ For instance, the 2001 Italian Census microdata only distinguish 15 places/regions of birth, compared to the 52 of Portugal or the 120 of Spain, which has forced the aggregation of information according to the limitations of the Italian information in order to make it fully comparable.
} 
the places of birth of their own interests, which are not necessary coincident across countries. So, even if our main research question focuses on the similarity or dissimilarity of the internal migration patterns by region of birth, we have to limit the number and types of categories to those available for all countries of study.

Figure 1.- Questions about migration in the Italian, Portuguese and Spanish Censuses of 2001

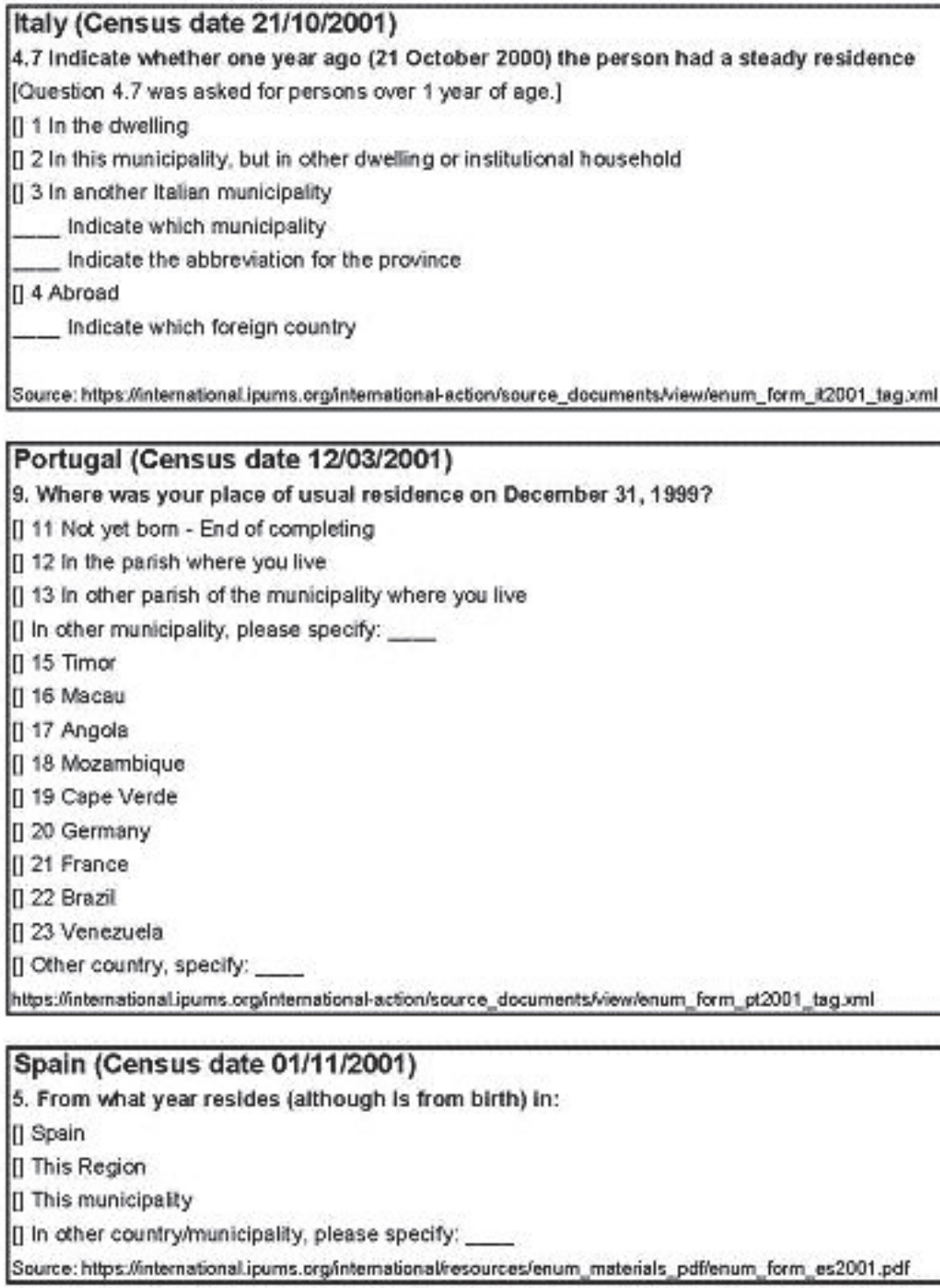

Source: Own elaboration based on the Integrated Public Use of International Microdata Series: version 5.0. Minneapolis: University of Minnesota, 2009 
The problem with some of the items is not related to the selected categories for the responses in each country but to the specific population that has been asked about them. For instance, employment status and academic attainment have been treated differently in the various censuses, depending on the age of the interviewee and his/her situation as an active/non-active citizen. In order to avoid the biased missing data derived from it, we have constricted our initial database to people aged 25 and over. In Table 2 we present the figures for the sample sizes and percentages of migrants by main individual characteristics and place of birth (native born and non-native born populations).

Table 2. - Incidence of migration by main individual characteristics. People aged 25 and over

\begin{tabular}{|c|c|c|c|c|c|c|c|c|c|}
\hline Explanatory variables & $\begin{array}{r}\text { It } \\
\text { Native- } \\
\text { born }\end{array}$ & $\begin{array}{r}\text { Foreign- } \\
\text { born }\end{array}$ & $\begin{array}{c}\% \\
\text { Foreign } \\
\text {-born }\end{array}$ & $\begin{array}{r}\text { Por } \\
\text { Native- } \\
\text { born }\end{array}$ & $\begin{array}{l}\text { tugal } \\
\text { Foreign-born }\end{array}$ & $\begin{array}{c}\% \\
\text { Foreign } \\
\text {-born }\end{array}$ & $\begin{array}{r}\text { Sp } \\
\text { Native-born }\end{array}$ & $\begin{array}{r}\text { Foreign- } \\
\text { born }\end{array}$ & $\begin{array}{c}\% \\
\text { Foreign } \\
\text {-born }\end{array}$ \\
\hline \multicolumn{10}{|l|}{$\operatorname{Sex}$} \\
\hline Male & $1,015,057$ & 39,991 & $3.8 \%$ & 157,092 & 10,186 & $6.1 \%$ & 661,965 & 36,395 & $5.2 \%$ \\
\hline Female & $1,121,794$ & 48,172 & $4.1 \%$ & 177,562 & 1,171 & $0.7 \%$ & 717,240 & 36,614 & $4.9 \%$ \\
\hline \multicolumn{10}{|l|}{ Age-group } \\
\hline 25-29 & 206,952 & 13,578 & $6.2 \%$ & 34,166 & 5,361 & $13.6 \%$ & 159,677 & 13,319 & $7.7 \%$ \\
\hline $30-44$ & 647,773 & 44,513 & $6.4 \%$ & 101,421 & 9,602 & $8.6 \%$ & 445,054 & 35,545 & $7.4 \%$ \\
\hline 45-59 & 554,954 & 16,130 & $2.8 \%$ & 90,169 & 3,696 & $3.9 \%$ & 347,338 & 13,725 & $3.8 \%$ \\
\hline $60-74$ & 482,588 & 8,985 & $1.8 \%$ & 74,584 & 1,914 & $2.5 \%$ & 280,842 & 7,503 & $2.6 \%$ \\
\hline $75+$ & 244,584 & 4,957 & $2.0 \%$ & 34,314 & 684 & $2.0 \%$ & 146,294 & 2,917 & $2.0 \%$ \\
\hline \multicolumn{10}{|l|}{ Marital status } \\
\hline Single & 420,249 & 20,597 & $4.7 \%$ & 40,822 & 5,227 & $11.4 \%$ & 292,446 & 21,704 & $6.9 \%$ \\
\hline Married/in union & $1,397,811$ & 57,373 & $3.9 \%$ & 248,742 & 14,075 & $5.4 \%$ & 898,490 & 42,003 & $4.5 \%$ \\
\hline Separated/Divorced & 88,013 & 4,945 & $5.3 \%$ & 12,162 & 1,101 & $8.3 \%$ & 51,395 & 5,242 & $9.3 \%$ \\
\hline Widowed & 230,778 & 5,248 & $2.2 \%$ & 32,928 & 854 & $2.5 \%$ & 128,722 & 3,528 & $2.7 \%$ \\
\hline \multicolumn{10}{|l|}{ Educational attainment } \\
\hline Less than primary & 170,941 & 5,654 & $3.2 \%$ & 195,977 & 4,448 & $2.2 \%$ & 246,982 & 8,423 & $3.3 \%$ \\
\hline Primary completed & $1,220,412$ & 41,031 & $3.3 \%$ & 77,542 & 6,883 & $8.2 \%$ & 690,809 & 30,904 & $4.3 \%$ \\
\hline Secondary completed & 575,072 & 32,427 & $5.3 \%$ & 35,332 & 5,352 & $13.2 \%$ & 330,203 & 25,150 & $7.1 \%$ \\
\hline University completed & 170,426 & 9,051 & $5.0 \%$ & 25,803 & 4,574 & $15.1 \%$ & 103,059 & 8,000 & $7.2 \%$ \\
\hline \multicolumn{10}{|l|}{ Housing tenure } \\
\hline Owned & $1,588,215$ & 41,748 & $2.6 \%$ & 256,277 & 14,996 & $5.5 \%$ & $1,174,372$ & 39,863 & $3.3 \%$ \\
\hline Not owned & 528,909 & 44,407 & $7.7 \%$ & 72,420 & 5,632 & $7.2 \%$ & 196,681 & 32,614 & $14.2 \%$ \\
\hline \multicolumn{10}{|l|}{ Employment status } \\
\hline employed & 957,344 & 49,274 & $4.9 \%$ & 181,526 & 15,447 & $7.8 \%$ & 620,650 & 40,775 & $6.2 \%$ \\
\hline unemployed & 140,313 & 8,091 & $5.5 \%$ & 11,092 & 1,072 & $8.8 \%$ & 87,088 & 6,960 & $7.4 \%$ \\
\hline inactive & $1,039,194$ & 30,798 & $2.9 \%$ & 142,036 & 4,738 & $3.2 \%$ & 663,315 & 24,742 & $3.6 \%$ \\
\hline
\end{tabular}

Source: Own elaboration based on the Integrated Public Use of International Microdata Series: version 5.0. Minneapolis: University of Minnesota, 2009 
We use different approaches to answer our research questions, according to the available data. First, we explore the data at an aggregated level and we calculate the Gross Migraproduction Rate (GMR). We also build up the profiles by age and sex. Then, we move to the micro perspective through some logistic models.

The gross migration rate is analogous to the gross fertility rate in that it is the sum of age specific migration intensities and it is interpreted as the mobility a person would experience in his life if he or she followed the pattern observed at a specific time point (by sex, age and whatever variables are considered to compute the rates). It measures the intensity of migration between two regions at a particular point in time (Willekens and Rogers 1986). In its simplest form it is defined as:

$$
G R M=\sum_{x=0}^{z} m_{x, x+n}
$$

where $m_{x, x+n}$ are the age-specific migration rates or transition probabilities ${ }^{10}$. This is way of standardizing age and gender structure that is sensitive to the starting and ending ages of summation (Bell, Blake et al. 2002).

Finally, we centre our attention on the individual characteristics that have an effect on the probability of having changed residence with regards to that stated for the previous year (Portugal, Italy and Spain). In this case we are not measuring migration intensity, but focusing on the personal circumstances that may act as push effects for migrating. In particular, we are especially interested in grasping the differences of behaviour according to the geographical origin (place of birth) of the migrants and whether their patterns are similar (or not) across countries.

For this purpose, we apply two sets of logistic models depending on the territorial unit under consideration. First, medium and long distance movements, defined by IPUMS International as changes between 'major administrative units' and, then, short distance

\footnotetext{
${ }^{10}$ In order to improve the robustness of the GMR estimations we have used ten-year groups from 0 to 80 and over. We have used different weights for males and females for the open group according to the differences in the life expectancy by sex. The data for Spain have been standardized to put them on the same level with the question about the residence one year before by applying different converters. Obviously, the GMR for the diverse groups are just comparable at an internal level.
} 
movements, defined as changes between 'minor administrative units' ${ }^{11}$. Information provided in the former case is available for all the analysed countries. We are aware that these minor and major administrative units differ, even if not significantly, with regards to their extension and population density, but since in this step we are studying individual propensities to move, instead of migration intensities, the territorial differences should not disturb our results too much.

The variables included in the logistic regression model are: sex, age group, place of birth, marital status, academic attainment, housing tenure and occupational status.

Thus, our dependent variables will be:

Model 1: Migration status -1 year ago. Same major administrative unit, value 0. Different major administrative unit, value 1 . Obviously, people who lived abroad at the time point of reference (1 year ago) are excluded from the data file.

Model 2: Migration status -1 year ago. Different minor administrative unit within the same major administrative unit, value 1 ; value 0 , otherwise. Obviously, people who lived abroad at the time point of reference ( 1 year ago) are excluded from the data file.

\section{3.- The context of international immigration in Italy, Portugal and Spain}

Before starting with the description of the internal migration characteristics, which is the objective of this work, we are going to provide some notes about the recent evolution of foreign immigration in Italy, Portugal and Spain.

The number of foreigners ${ }^{12}$ who were registered in Italy, Portugal and Spain in 2000 according to the OECD information was 2.96 million, figure that evolved rapidly in the following years and was multiplied by almost four nine years later, reaching a total of 10.4 million of foreigners. The growth levels in the three countries were different. Spain was the

\footnotetext{
11 The model with place of residence a year ago (different major administrative unit) corresponds to the interprovincial migrations with a mean migration distance over $100 \mathrm{~km}$. we consider them as medium-long distance migration. On the contrary, the model Different minor administrative unit within the same major administrative unit corresponds essentially to migratory movements associated to changes of residence.

12 The Italian data provided by the Eurostat and the OCDE do not allow for the creation of an annual population series by country of birth, which is possible with the Portuguese and Spanish data. We have, thus, decided to present the data on the citizenships present in the three countries.
} 
country with a higher increase between 2000 and 2009, 4.16 times the initial stock of foreigners, whilst in Portugal the final stock was 2.2 times higher.

These data explain why Spain concentrated the greatest deal of the flows. In 2006, 80 out of every 100 entries in the analysed region were for Spain. In this context of immigration expansion, the timing of the inflows differs considerably across the selected countries: the peak of immigration is observed in 2004 for Italy, 2001 for Portugal and 2007 for Spain. The economic crisis leaded to a fall in the inflows to Spain, reducing them to almost half the previous amount between 2007 and 2009, whilst Italy and Portugal registered a slight increase in the inflows for the same period.

As a result of these trends, the share of the foreigners in the total population experienced a relevant growth (Table 3). If the three countries showed proportions between 2.03 and 3.4 in the beginning of 2000, a decade after the weight of the foreigners in Spain was 12.4 per cent, 7.1 per cent in Italy and 4.3 per cent in Portugal, figures that underestimate the real impact of immigration, due to the process of acquisition of citizenship ${ }^{13}$. In this sense, the Southern Mediterranean countries experienced in just a few years a migratory cycle that took decades in other Northern Europe countries.

During this period the population pyramid of the foreigners is fed by the labour migratory streams, essentially constituted by youth, with a mean age slightly over 30 . In fact, the first effect of the immigration on the population structures in the Southern European countries was the widening of the base, i.e. the higher relative presence of younger age-groups. Regarding the equilibrium by gender, in 2001 the foreign born population tended towards the feminine side in Italy and Portugal, with a sex ratio of 0.86 and 0.94 respectively and slightly towards the masculine side in Spain (1.01). However, these general values omit important disparities by continent of origin (Table 4): the Africans are heavily masculinised in Italy and Spain, as opposed to Portugal. A similar pattern is followed by the Asians, with lower values, whilst the group of Europeans and Latin-Americans are characterised by a major feminisation, more intense for the Latin-Americans in Italy and Spain.

\footnotetext{
${ }^{13}$ For instance, the proportion of foreign population in Spain was $12.2 \%$, while the proportion of foreignborn population was $14.0 \%$.
} 
Table 3.- Stocks and inflows of foreign population by year and country of residence in Southern Europe (2000-2009)

\begin{tabular}{|c|c|c|c|c|c|c|c|c|c|c|}
\hline \multirow{2}{*}{$\begin{array}{l}\text { Country of } \\
\text { residence }\end{array}$} & \multicolumn{10}{|c|}{ Stocks of foreign population by year and country of residence in Southern Europe (Thousands) } \\
\hline & 2000 & 2001 & 2002 & 2003 & 2004 & 2005 & 2006 & 2007 & 2008 & 2009 \\
\hline Italy & 1379.7 & 1448.4 & 1549.4 & 1990.2 & 2402.2 & 2670.5 & 2938.9 & 3432.7 & 3891.3 & 4235.1 \\
\hline Portugal & 207.6 & 360.8 & 423.8 & 444.6 & 469.1 & 432.0 & 437.1 & 446.3 & 443.1 & 457.3 \\
\hline Spain & 1370.7 & 1977.9 & 2664.2 & 3034.3 & 3730.6 & 4144.2 & 4519.6 & 5268.8 & 5648.7 & 5708.9 \\
\hline \multirow{2}{*}{$\begin{array}{l}\text { Country of } \\
\text { residence }\end{array}$} & \multicolumn{10}{|c|}{ Percentage of foreign population by year and country of residence in Southern Europe } \\
\hline & 2000 & 2001 & 2002 & 2003 & 2004 & 2005 & 2006 & 2007 & 2008 & 2009 \\
\hline \multirow{3}{*}{$\begin{array}{l}\text { Italy } \\
\text { Portugal } \\
\text { Spain }\end{array}$} & 2.41 & 2.53 & 2.70 & 3.46 & 4.17 & 4.59 & 5.03 & 5.83 & 6.56 & 7.09 \\
\hline & 2.03 & 3.51 & 4.09 & 4.26 & 4.47 & 4.10 & 4.13 & 4.21 & 4.17 & 4.30 \\
\hline & 3.40 & 4.86 & 6.45 & 7.22 & 8.74 & 9.55 & 10.26 & 11.74 & 12.39 & 12.43 \\
\hline \multirow{2}{*}{$\begin{array}{l}\text { Country of } \\
\text { residence }\end{array}$} & \multicolumn{10}{|c|}{$\begin{array}{c}\text { International inflows of foreign population by year and country of residence in Southern Europe } \\
\text { (Thousands) }\end{array}$} \\
\hline & 2000 & 2001 & 2002 & 2003 & 2004 & 2005 & 2006 & 2007 & 2008 & 2009 \\
\hline Italy & 271.5 & 232.8 & 388.1 & & 319.3 & 206.8 & 181.5 & 252.4 & 286.2 & \\
\hline Portugal & 15.9 & 151.4 & 72.0 & 31.8 & 34.1 & 28.1 & 22.5 & 32.6 & 32.3 & 33.8 \\
\hline Spain & 330.9 & 394.0 & 443.1 & 429.5 & 645.8 & 682.7 & 803.0 & 920.5 & 692.2 & 469.3 \\
\hline
\end{tabular}

Source: Own elaboration with data from www.oecd.org/migration/imo

Table 4.- Sex-ratio and geographical origin of immigrants in Southern Europe (2001)

\begin{tabular}{|l|c|c|c|c|c|c|}
\hline \multirow{2}{*}{$\begin{array}{c}\text { Country of } \\
\text { residence }\end{array}$} & \multicolumn{6}{|c|}{ Sex ratio of immigrants by continent of birth } \\
\cline { 2 - 7 } Italy & Foreign born & Africa & Asia & Europe & Latin America & Rest of World \\
Portugal & 0.86 & 1.41 & 1.01 & 0.77 & 0.60 & 0.70 \\
Spain & 0.97 & 0.96 & 0.98 & 1.01 & 0.93 & 0.90 \\
\hline Total & 1.01 & 1.66 & 1.28 & 0.98 & 0.81 & 0.91 \\
\hline \multirow{2}{*}{$\begin{array}{c}\text { Country of } \\
\text { residence }\end{array}$} & 0.94 & 1.33 & 1.08 & 0.85 & 0.76 & 0.76 \\
\cline { 2 - 7 } Italy & Foreign born & Africa & Asia & Europe & Latin America & Rest of World \\
Portugal & $100 \%$ & $19.7 \%$ & $9.2 \%$ & $55.7 \%$ & $11.2 \%$ & $4.2 \%$ \\
Spain & $100 \%$ & $54.0 \%$ & $2.3 \%$ & $29.9 \%$ & $11.4 \%$ & $2.5 \%$ \\
\hline Total & $100 \%$ & $19.1 \%$ & $4.2 \%$ & $36.4 \%$ & $39.0 \%$ & $1.3 \%$ \\
\hline
\end{tabular}

Source: Own elaboration based on Integrated Public Use Microdata Series International: version 5.0. Minneapolis: University of Minnesota, 2009 
On the other hand, the geographical composition of the population born abroad for each country of residence gives some evidence of the focalization of the different groups on certain destinations. In 2001, the Europeans were the most numerous collective in Italy (55.7\%), the Africans in Portugal (54.0\%) and the Latin-American in Spain (39.0\%). in fact, the latter showed the most heterogeneous range of origins. It has to be highlighted that the national composition of each group of immigrants showed relevant divergences in the cross-country comparison. For instance, amongst the European immigrants, the Albanians occupied the first position in Italy according to the ISTAT data for 2002. In Spain, the most represented European collective were the Germans according to INE data. With regards to the other groups, in Portugal the colonial relationships with Africa and the historical and linguistic bonds with Brazil nourished an important share of the new immigration. In Spain, the European immigration of the elders coming from Germany, Great Britain and France, the African immigration with origin in Morocco and the new inflows of Latin-Americans coming from Colombia and Ecuador constituted the majority of the immigration flows.

In brief, the structural similarities in the calendar and the intensification of the immigration flows in the South of Europe should not prevent us to remember that the composition by origin is country-specific and that some differentiated behaviours with respect to the internal migration are derived from the continental aggregation we have had to assume. We discuss this fact in the following pages.

\section{4.- Migration intensity and continent of birth}

Demographers have observed important regularities in the migratory profiles by age in a wide set of developed countries (Rogers and Willekens 1986) ${ }^{14}$. This migratory profile is characterized by the higher mobility of young adults, between 20 and 39 years old, linked to work, marriage and house searching, and the relevant mobility of children and teenagers (0-16 years old), that reflect their parents' mobility. It is more elevated during the first ages because they are often children of young parents that belong to the age segment with the

\footnotetext{
${ }^{14}$ Demographers have associated these regularities to the influence of different events and life cycle stages: job search, getting married and family formation, migration at dependent ages and low labour mobility from certain ages.
} 
highest mobility; and the low mobility after 40, when job searching and household formation are considerably reduced; finally, the likely appearance of a second mobility maximum, of minor intensity, around those ages in which people use to get retired. One of our research questions is: to what extent does this general pattern remain as we consider the migration rates by places of origin (continents of birth and destination countries)?

In order to compare the distribution by age of the migration rates, we have to avoid the scale factor by obtaining the weight of each age group over the GMR total. As we can observe in Figure 2, the migration schedule presents relevant differences between native and non-native born populations for all the analysed countries (Italy, Portugal and Spain). Even so, profiles by age are very similar among non-natives in the three countries (Figure 2).

Figure 2.- Standardized age rates of internal migration of Southern Europe by sex, age and place of birth

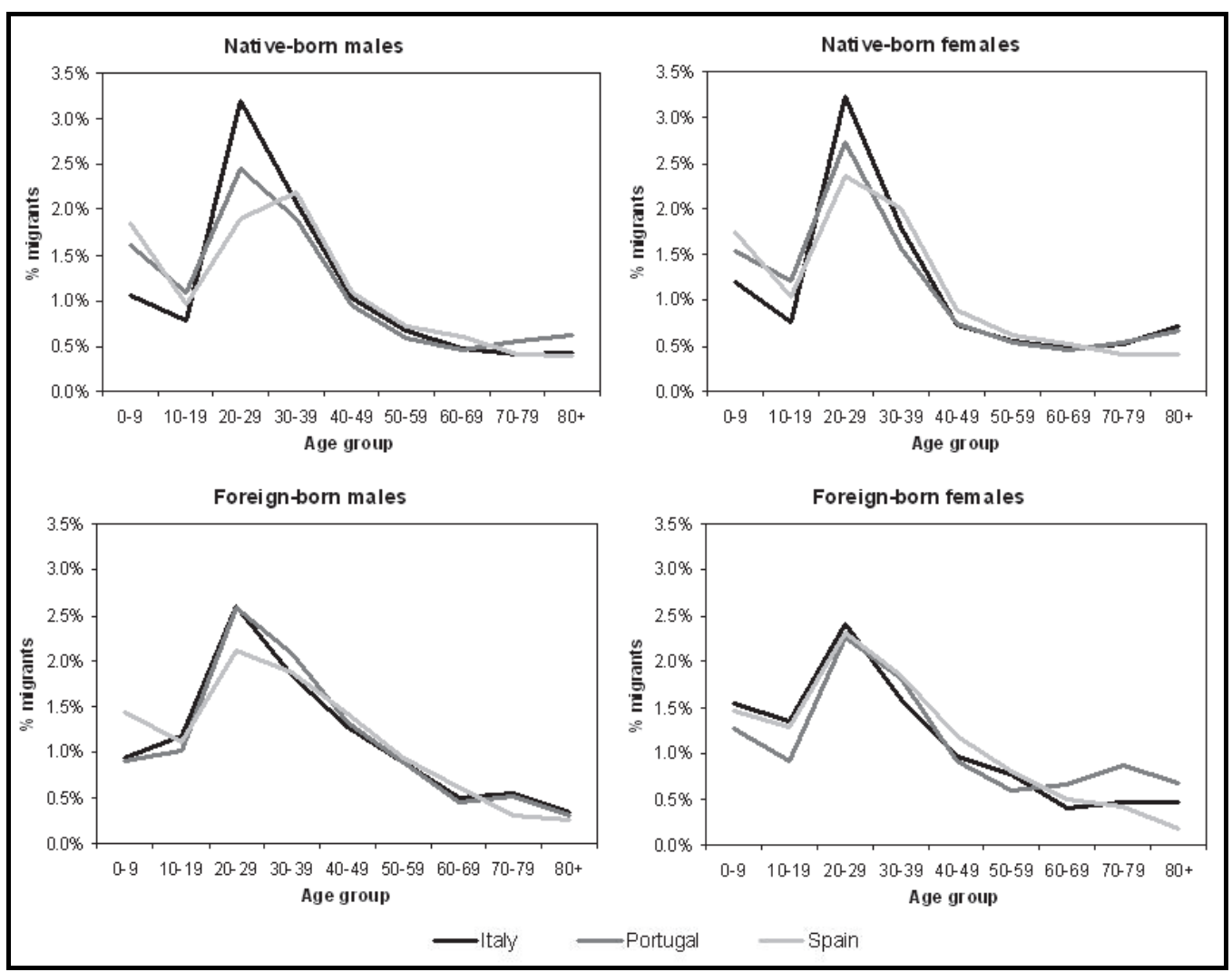

Source: Own elaboration based on the Integrated Public Use of the Microdata International Series: version 5.0. Minneapolis: University of Minnesota, 2009 
Nonetheless, the most important differences are found in the schedule of the native-born population in the different countries. On the other hand, the peak for the young people group is higher among the native-born population, spreading to a wider range of ages for the foreign-born population. This suggests a lesser life-cycle stage dependency of migration amongst those collectives born abroad. In other words, socio-economical factors on mobility are active more years for the group of foreign-born population. Finally, we do not find important differences by sex regarding the schedule of native and foreign-born populations, although these results will be further explained through Figure 3.

In Figure 3, rates by sex, age and continent of birth are shown for the selected countries. Because of the reasons already stated in the methodological section, the results by group of immigrant origin are comparable only within each country. As it can be observed, the analysed groups present different migration profiles, both in intensity and shape. Attending to the place of birth, we can argue that the Europeans have a very similar age profile to that of native-born population in most of the countries, and low differences by sex are observed. The people of African origin manifest a pattern which is predominantly masculine at all ages, especially in Spain and Italy, where there are remarkable differences by gender in the intensity. The important mobility experienced by the Africans, aged between 20 and 49, means the existence of a hyper-mobility pattern that contrasts with the migration profile that can be found in the native-born population (Recaño-Valverde 2003). The Latin-American pattern is characterized, on the contrary, by the more important protagonist role of the females and their more outstanding trend towards family migration. Finally, the Asians concentrate a great deal of the migratory intensity around the young people, with a higher presence of males in both types of mobility.

The demographic indicators of internal migration of native and non-native born populations present very disparate values in their intensity (Table 5). Generally, the changes of residence by foreign-born population are appreciably more numerous than those by native-born individuals. Differences on mobility between native and foreign-born populations are always more outstanding in the medium and long distance migration. Another important distinction is found in the extreme variation of the indicators as we consider the continents of origin. In sum, the population born abroad that changes residence effectuates an amount of movements in the short distance mobility that is almost 70-90 per cent higher than that of native-born population in Italy, Spain and Portugal for the same type of migration. On the other hand, the previous differences in Italy and 
Portugal remain and are even more highlighted now in countries like Spain, where long distance mobility of males born in another country is 2.12 times higher than that of the Spanish-born population.

Figure 3.- Internal migration rates by sex, age and continent of birth
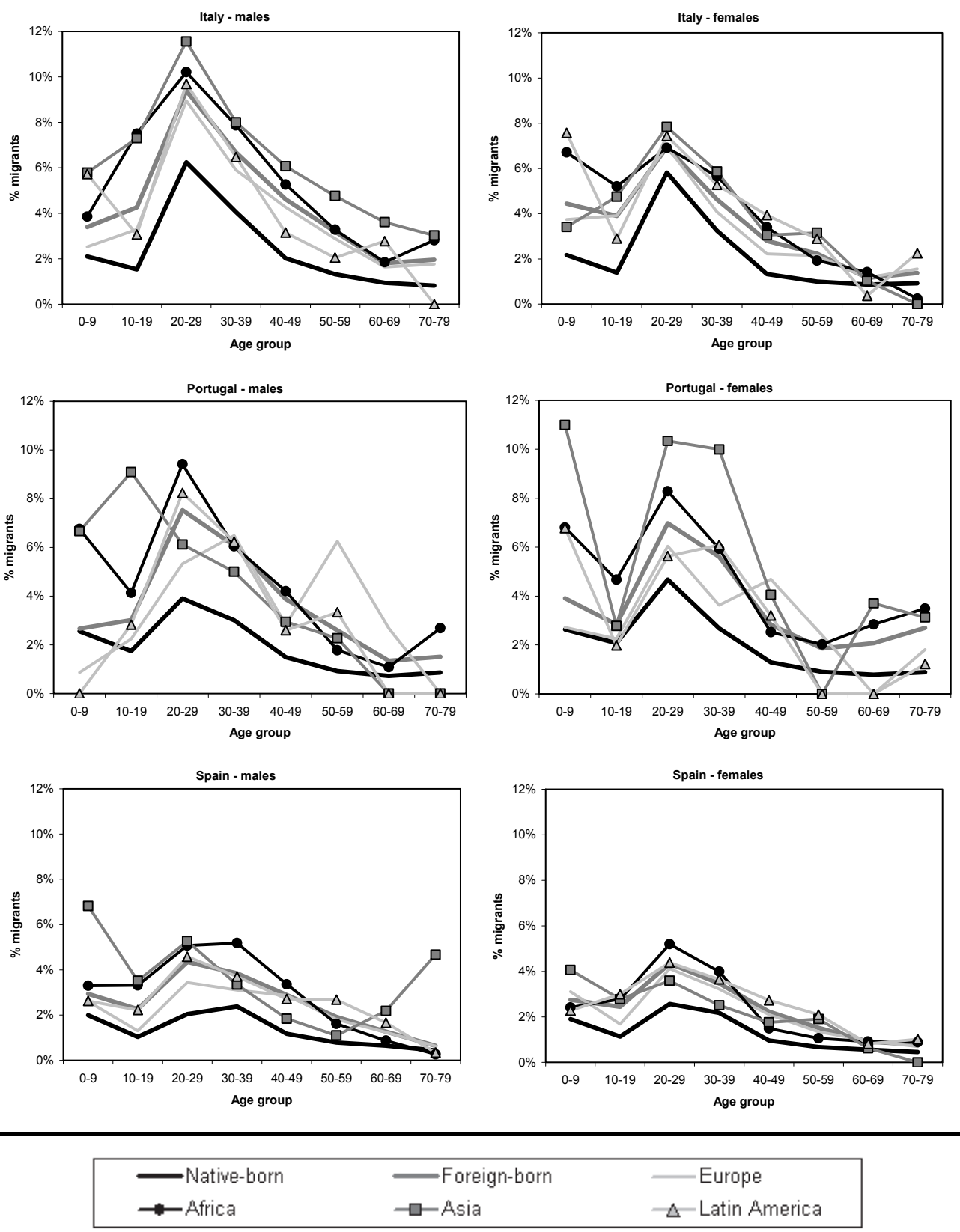

Source: Own elaboration based on the Integrated Public Use of the Microdata International Series: version 5.0. Minneapolis: University of Minnesota, 2009 
People born in Africa, Latin-America and Asia present the highest mobility levels, much higher than those of the Europeans. North-Americans represent a special case, since they seem to transfer the high mobility in their countries of origin to the countries where they have emigrated to.

Table 5.- Demographic indicators by type of migration and continent of birth (2000-2001)

\begin{tabular}{|c|c|c|c|c|c|c|c|c|}
\hline \multirow[b]{3}{*}{ Country } & \multicolumn{8}{|c|}{ Gross migraproduction rate (GMR) } \\
\hline & \multicolumn{8}{|c|}{ Same major, different minor administrative unit (Short distance) } \\
\hline & Gender & Native-born & Foreign-born & Europe & North America & Africa & Asia & Latin America \\
\hline \multirow[b]{2}{*}{ Italy } & Males & 1.20 & 2.36 & 1.95 & 1.84 & 3.17 & 3.15 & 2.61 \\
\hline & Females & 1.23 & 1.95 & 1.74 & 0.87 & 2.55 & 2.01 & 2.52 \\
\hline \multirow[b]{2}{*}{ Portugal } & Males & 0.86 & 1.57 & 1.31 & 0.85 & 2.08 & 2.72 & 1.45 \\
\hline & Females & 0.90 & 1.60 & 1.40 & 0.57 & 2.00 & 2.32 & 1.63 \\
\hline \multirow[b]{2}{*}{ Spain } & Males & 0.71 & 1.23 & 1.16 & 1.17 & 1.21 & 1.47 & 1.31 \\
\hline & Females & 0.70 & 1.16 & 1.11 & 1.18 & 1.17 & 0.76 & 1.24 \\
\hline \multicolumn{9}{|c|}{ Different major administrative unit (medium/long distance) } \\
\hline Country & Gender & Native-born & Foreign-born & Europe & North America & Africa & Asia & Latin America \\
\hline \multirow[b]{2}{*}{ Italy } & Males & 0.76 & 1.26 & 1.25 & 0.72 & 1.14 & 2.45 & 0.89 \\
\hline & Females & 0.58 & 0.93 & 0.95 & 0.61 & 0.81 & 0.90 & 1.08 \\
\hline \multirow[b]{2}{*}{ Portugal } & Males & 0.72 & 1.36 & 1.36 & 0.52 & 1.53 & 1.05 & 0.88 \\
\hline & Females & 0.81 & 1.49 & 0.96 & 0.43 & 1.85 & 2.33 & 1.39 \\
\hline \multirow[b]{2}{*}{ Spain } & Males & 0.37 & 0.82 & 0.55 & 1.43 & 1.14 & 1.40 & 0.82 \\
\hline & Females & 0.39 & 0.72 & 0.63 & 0.59 & 0.71 & 0.96 & 0.81 \\
\hline \multirow[b]{3}{*}{ Country } & \multicolumn{8}{|c|}{ Sex ratio of $G M R$} \\
\hline & \multicolumn{8}{|c|}{ Same major, different minor administrative unit by continent of birth } \\
\hline & Gender & Native-born & Foreign-born & Europe & North America & Africa & Asia & Latin America \\
\hline Italy & $\begin{array}{c}\text { Sex } \\
\text { ratio }\end{array}$ & 0.98 & 1.21 & 1.12 & 2.11 & 1.24 & 1.57 & 1.03 \\
\hline Portugal & $\begin{array}{c}\text { Sex } \\
\text { ratio } \\
\end{array}$ & 0.97 & 0.98 & 0.93 & 1.48 & 1.04 & 1.17 & 0.89 \\
\hline Spain & $\begin{array}{c}\text { Sex } \\
\text { ratio }\end{array}$ & 1.02 & 1.06 & 1.05 & 0.99 & 1.03 & 1.93 & 1.05 \\
\hline \multirow[b]{2}{*}{ Country } & \multicolumn{8}{|c|}{ Different major administrative unit by continent of birth (2000-2001) } \\
\hline & Gender & Native-born & Foreign-born & Europe & North America & Africa & Asia & Latin America \\
\hline Italy & $\begin{array}{c}\text { Sex } \\
\text { ratio }\end{array}$ & 1.31 & 1.35 & 1.32 & 1.19 & 1.40 & 2.70 & 0.83 \\
\hline Portugal & $\begin{array}{c}\text { Sex } \\
\text { ratio }\end{array}$ & 0.89 & 0.91 & 1.42 & 1.20 & 0.83 & 0.45 & 0.63 \\
\hline Spain & $\begin{array}{c}\text { Sex } \\
\text { ratio }\end{array}$ & 0.95 & 1.14 & 0.87 & 2.41 & 1.61 & 1.46 & 1.01 \\
\hline
\end{tabular}

Source: Own elaboration based on the Integrated Public Use of the Microdata International Series: version 5.0. Minneapolis: University of Minnesota, 2009. 
A second factor to bear in mind is the existence of important gender differences among the foreign-born populations. Whilst among Europeans the mobility intensity is similar for males and females, the migrations of Africans and Asians show much higher intensities among men (table 5). On the contrary, Latin-American women change residence with higher intensity. In brief, immigrants from Asia and Africa present an internal mobility pattern primarily masculine, fact that is reversed as we consider the Latin-American and European populations. Nonetheless, the composition by nationalities of the selected groups in the countries of destination has an important effect on these results. In Italy, where the Albanians are the most represented European origin, the gender differences are more obvious and do favour males, especially in the medium-long distance migration.

Two reasons help to explain the interactions between gender, place of birth and country of residence. With regards to the differences by country of origin, preliminary works about internal migration in the developing countries (United Nations 1993; Hugo 1993; Bilsborrow 1993), and specifically the data by sex and age estimated by Singelmann (1993) for 47 countries, show a tight association between the gender differences by age, the change in the woman status during the life cycle and the high differences in internal migration intensity in favour of males in the African and Asian countries (mainly in the Arabic countries of the Asian continent). This relationship is modified by the influence of some cultural determinants that have to do with the female conditions, not easy to quantify for the moment, that seem to explain the great spatial variability of gender relationships in the countries of origin. But these cultural differences that have been transferred to the countries we study may be fostered by other socio-economical reasons, especially linked to the role that non-native males and females have in the labour markets of the corresponding countries of residence. For instance, in the case of Spain, the seasonal low qualified works (Recaño-Valverde 2003; De Miguel, Solana and Pascual 2007) that African and Asian male labourers assume in sectors such as agriculture and construction mean continuous longer or shorter migrations to the places where this labour demand is generated. The higher differences in the migration intensity by sex found for the medium and long distance mobility among the Africans and Asians in Italy and Spain lend weight to his interpretation. 


\section{5.- The individual determinants of internal migration}

We discuss now the findings regarding the individual determinants of migration. The results obtained from the micro perspective confirm those previously discussed for the aggregated data for sex, age and place of birth. The general pattern of most of the explanatory variables is similar across-countries when we study medium-long and short distance migration (Table 6), although the magnitude of the coefficients varies. The oddsratios of having experienced this sort of mobility (medium-long distance migration) in the previous year are always lower for females than males, although Italian women move much less than those in the rest of the countries (around 69 females for every 100 males). According to the short distance mobility, women still move less, although in general the estimators are now closer to one, pointing out that the gap with regards to men has shortened. This result was quite expectable, since this kind of migration is mainly associated to residential mobility and not so much to labour market adjustments. Change of municipality responds often to the necessity of varying house conditions, thus pushing the family unit (or just some members) to move to a new dwelling. In many of these cases, the previous life space may not even be affected.

As we showed before, with the aggregated data, the younger group (25-29) is more likely to move for all of the time intervals considered and the probability of having migrated in the previous year/s decreases with age. The gap between the baseline category and the following one (30-44) is lower Spain (regarding migration in the last year). It is also in Spain where estimators for people over 74 are higher, odds-ratio explained by a highest incidence of strategies associated to entry in widowhood and the search of geographical proximity (if not cohabitation) to any of the children. Also return movements of former inter-regional emigrants could have some weight on this group, but this partial effect should explain more about propensity to move of people aged 60-74, at least in the countries were the time point reference is one year ago. Something similar is observed for the influence of age groups in short-distance migration. They follow the general trend already discussed for inter major administrative unit migration, but we also find slight differences for older groups in Italy and Portugal that reveal the increase in the probability of having changed municipality of residence during the previous year of those aged 75 and over, in relation to the precedent category. That is, maybe a situation of more dependency explains this discrete augment in their mobility. Residential strategies linked to a 
deterioration of the health conditions may be one of the main reasons for this finding: people moving to one of their children's home or getting a place to live that it is closer to them.

Table 6.- Odds ratios for migrating by type of migration

\begin{tabular}{|c|c|c|c|c|c|c|}
\hline \multirow[b]{2}{*}{ Explanatory variables } & \multicolumn{3}{|c|}{ Short distance } & \multicolumn{3}{|c|}{ Medium/long distance } \\
\hline & Italy & Portugal & Spain & Italy & Portugal & Spain \\
\hline \multicolumn{7}{|l|}{$\operatorname{Sex}$} \\
\hline $\begin{array}{r}\text { male } \\
\text { female }\end{array}$ & $.919 *$ & $.904 *$ & $.911^{*}$ & $.687 *$ & $.861 *$ & $.893 *$ \\
\hline \multicolumn{7}{|l|}{ age group } \\
\hline $25-29$ & & & & & & \\
\hline $30-44$ & $.575^{*}$ & $.487 *$ & $.512 *$ & $.518^{*}$ & $.555^{*}$ & $.692 *$ \\
\hline $45-59$ & $.254^{*}$ & $.225^{*}$ & $.232 *$ & $.233^{*}$ & $.265^{*}$ & $.376^{*}$ \\
\hline $60-74$ & $.195^{*}$ & $.136^{*}$ & $.179^{*}$ & $.170 *$ & $.280 *$ & $.335 *$ \\
\hline $75+$ & $.259 *$ & $.228^{*}$ & $.164 *$ & $.164 *$ & $.275^{*}$ & $.344 *$ \\
\hline \multicolumn{7}{|l|}{ place of birth } \\
\hline $\begin{array}{r}\text { native-born } \\
\text { non-native born }\end{array}$ & & & & & & \\
\hline Africa & $2.153^{*}$ & $1.678^{*}$ & $1.958^{*}$ & $1.315^{*}$ & $1.789 *$ & $2.283 *$ \\
\hline Latin-America & $1.696^{*}$ & $1.612 *$ & $1.796^{*}$ & $1.271 *$ & $1.558^{*}$ & $1.869 *$ \\
\hline North-America \& Oceania & 0.851 & .614 & 1.08 & 1.149 & 0.691 & 1.378 \\
\hline Asia & $1.934 *$ & 1,485 & 1.124 & $2.107 *$ & $1.971 *$ & $1.769 *$ \\
\hline Europe & $1.391 *$ & $1.194 * *$ & $1.690^{*}$ & $1.551 *$ & $1.540 *$ & $1.253 *$ \\
\hline \multicolumn{7}{|l|}{ marital status } \\
\hline $\begin{array}{r}\text { single/never married } \\
\text { married/in union }\end{array}$ & $.920 *$ & $1.994 *$ & $1.511 *$ & $.500 *$ & $1.092 * *$ & 1.000 \\
\hline separated/divorce & $2.431^{*}$ & $3.563^{*}$ & $2.765^{*}$ & $.925^{*}$ & $2.140^{*}$ & $1.693 *$ \\
\hline widowed & $1.420 *$ & $2.698^{*}$ & $1.874 *$ & $.706^{*}$ & $1.593 *$ & 1.123 \\
\hline \multicolumn{7}{|l|}{ educational attainment } \\
\hline $\begin{array}{l}\text { less than primary completed } \\
\text { primary completed }\end{array}$ & $1.166^{*}$ & $1.498^{*}$ & $1.269 *$ & $1.091^{* *}$ & $1.510 *$ & $1.217 *$ \\
\hline secondary completed & $1.434 *$ & $2.285^{*}$ & $1.936^{*}$ & $1.905^{*}$ & $2.384 *$ & $1.792 *$ \\
\hline university completed & $1.771 *$ & $2.989^{*}$ & $2.175^{*}$ & $3.944 *$ & $4.091 *$ & $2.683 *$ \\
\hline \multicolumn{7}{|l|}{ housing tenure } \\
\hline $\begin{array}{r}\text { owned } \\
\text { not owned }\end{array}$ & $1.235^{*}$ & $1.175^{*}$ & $1.339^{*}$ & $1.529 *$ & $1.689 *$ & $3.372 *$ \\
\hline \multicolumn{7}{|l|}{ employment status } \\
\hline $\begin{array}{r}\text { employed } \\
\text { unemployed }\end{array}$ & $.632 *$ & 1,011 & $.944 * *$ & $.936^{*}$ & $1.682 *$ & $1.614 *$ \\
\hline inactive & $.788^{*}$ & $.772 *$ & $.854^{*}$ & $1.305 *$ & $1.300 *$ & $1.123 *$ \\
\hline constant & $.029 *$ & $.010^{*}$ & $.010^{*}$ & $.017 *$ & $.008 *$ & $.004 *$ \\
\hline
\end{tabular}

Source: Own elaboration based on the Integrated Public Use of the Microdata International Series: version 5.0. Minneapolis: University of Minnesota, 2009 
In medium-long distance migration, attending the place of birth, we observe that the geographical origin does not affect exactly in the same way as we compare by country of residence. Generally, nonetheless, the trend observed with the aggregated data for most of the analysed countries of a higher mobility of the non-native born people persists after controlling by other socio-demographic variables. Asians propensity to emigrate in the last year is higher than that of the rest of the immigrant origins in Italy and Portugal, and it is also quite high in Spain. The history of immigration in each destination helps to clarify the differences. Immigration flows of Asians are recent in the majority of Southern-European countries, for instance. In any case, the longer the time spent in the country, the lower the likelihood to change region of residence. Mobility of people born in Africa doubles that of people born in Spain, and almost doubles that of people born in Portugal (despite the fact that major collectives in this category are, for both destinations, originally from different African countries). We cannot affirm, thus, that groups sharing this continent of birth have the same internal migratory patterns in the countries where they live. Europeans tend to migrate more than native-born population. We have to take into account that, due to the variability on the data sources, we have not been able to disaggregate more the categories of the place of birth. Europe, as the rest of continents (except maybe for North America and Oceania) groups a heterogeneous profile of immigrants from very diverse origins. In Spain, for instance, where their mobility is somehow higher than that of natives, the presence of foreign-born people from Western European countries that change residence for reasons frequently associated to better their quality of life (climate, etc) share category with the so-called labour immigrants from Eastern countries of birth.

After Africans, Latin-Americans' mobility is particularly high in Spain, after controlling for the rest of the explanatory variables, almost doubling mobility of Spanish-born population. This collective also shows a high probability to have experienced a recent move in Portugal, with odds close to 1.6. It is interesting to go back to the results for aggregated data that manifested a certain anomalous behaviour of this collective in Spain, where their mobility is over-dimensioned.

With regards to place of birth, the position of Latin-Americans has been modified and, comparing to them in short-distance migration, Africans and Asians have in this case lower estimators. Latin-Americans move, controlling by the rest of the covariates and compared to the other continents of births, more at short than long-distances. The role of Africans is especially interesting since, it is the group with highest probabilities of having moved in 
Italy, Spain and Portugal. Also in the three countries (Portugal, Spain and Italy), LatinAmericans have high odds-ratio of moving. Europeans, on the other hand, are more likely to change municipality in Spain, whilst Asians are more mobile in Italy. In general, however, these three Western-Mediterranean countries (Portugal, Spain and Italy) show more similar patterns.

The effect of marital status differs across countries. Relationships within the family do vary depending on the cultural norms prevalent in the different contexts. Those categorised as single are more willing to move in Italy, but separated or divorce subjects have a higher odds-ratio in almost all countries of having experienced a medium-long distance migration in the last year, maybe often as a consequence of their entry in this status. After them, the widows get the highest values, probably because of the same reason. Maybe they have fewer commitments that link them to the place of residence or maybe it is the change in their marital condition which implies the new mobility.

As we saw for medium-long distance, marital status does not have the same influence across countries. In fact, the divorced and separated are the ones with highest coefficients in all countries, as we suggested before, mobility in these cases could be partially understood as a consequence of a change in the marital status.

Also generalized it is the fact that the higher the academic attainment, the higher the oddsratio of having emigrated in the period considered. People with a university degree move four times more (all other variables set to zero) than people with no completed studies in Portugal and Italy and around three times more in Spain, for which show the smallest differences between the extremes. It is interesting to highlight this effect of education since inter-regional migration in certain countries, such as Italy and Spain, was in recent past associated to labour mobility, following to some extent the same patterns than international immigrants would eco years after. In 2000-2001, controlling by the rest of the explanatory variables, medium and long distance migration is more frequently experienced by those who are best prepared in terms of formal education.

There is no doubt (despite the differences in the magnitudes across countries) about the influence of the academic attainment. It is for long distance mobility, but also for short distance, that those who are more likely to migrate are the best prepared. The differences are more noticeable in Portugal and less relevant in Italy, but the results are really consistent for all data sets and territorial perspectives of analysis. The higher the formal education received, the higher the chance to migrate, regardless place of birth, sex, age, 
etc. This break is a trend that characterized some of these countries in recent periods in past, when labour migration would affect persons with low qualifications.

The fact of not owning the dwelling has a relatively important positive effect across the selected countries. Ownership of the house is the most relevant explanatory element in Spain, country where on the other hand the incidence of owned dwellings is particularly high. Having a property prevents from emigrating to another major administrative unit.

The ownership condition (even if the property is not totally paid) prevents from moving, since this circumstance normally roots the person (or the family unit) to the place of residence. Even though, coefficients are in general lower for non-owners than in the case of medium-longer distance, indicating that those who do not own the dwelling have higher odds-ratio to be living in a different major administrative unit a year ago than to be living in a different minor administrative unit, the rest of variables kept constant. Obviously, part of the explanation relies on the fact that part of the inter-municipal mobility is an effect of the acquisition of a house.

People who are unemployed or inactive at the time of the Census are, in general, more likely to have migrated (medium-long distance) in the previous year than employed people. It is reasonable to state that persons who have a stable employment situation would be more reluctant to change province/region of residence (unless it is a job requirement) than a person who is jobless or have not that sort of tight to place (students, retired people, etc). Something similar happens in Italy for the unemployed, although the coefficient is quite proximate to unity, indicating that differences are modest. Finally, the behaviour observed according to the employment status, is the same for all countries in short-distance migration. People who are unemployed by the time of the Census data collection have estimators are really close to one in Portugal and Spain (showing not relevant differences with regards to employed population) and even lower to one in Italy. Short distance migration, as we have mentioned before, is not so much related to the labour market demand as in the medium-long distance, so it is somehow predictable that change of residence within the major administrative unit in the countries where these units do not imply much distance correspond more often to people who are employed and can afford a new house.

In sum, results for short distance mobility do not differ much from those for medium and long distance. 


\section{6.- Discussion and conclusion}

The research questions we have proposed at the beginning of this chapter have been partially answered.

The response to the first one (are the demographic patterns of internal migration of foreignborn similar to those of natives by age and sex?) is negative. The pattern by age of native and non-native populations differs significantly. Also, the intensity of internal migration of the foreign-born population is notably higher than that of the native-born population.

The answer for the second question (do these migration patterns differ by immigrant origin?) is positive again. The population born in Africa, Asia and Latin America extends their internal mobility to all active age groups in contrast to the migration pattern of the native-born; the profile of age migration rates of the Europeans and native-born population are quite similar. However, important differences on intensity are found for the foreign population. Especially, people born in the Asian and African continents show the highest intensities. Another interesting finding is that male mobility predominates amongst immigrants of African and Asian geographical origin, but this trend is reversed for the Latin-American population. The European countries do not manifest important differences by gender.

Are the observed demographic patterns by specific national groups always the same or do they differ by the country of destination? The response is now ambiguous. The sex and age structures by continent of origin and country of residence are very similar (and possibly affected by the limitations of the sample), but the intensities vary according to the country of residence and the region of birth, especially as we observe the GMR ratios for men and women. We presume that the national composition of each continental group, which we have not been able to analyse properly, may explain this result. We have to bear in mind that the majority nationalities that integrate the European, Asian and Latin-American collectives are not the same in the three countries of residence we have compared.

What are the effects of the individual characteristics on the internal migration of foreigners as we compare by country of residence? In short, our findings in this regard confirm the results offered by the international academic literature for other contexts. Logistic models show that general patterns by place of birth, after controlling for other socio-demographic characteristics, are similar to those already discussed for aggregated data. Females tend to 
move less and gender differences are higher for medium and long distance migration than they are for short distance mobility. In Italy, the gap between females and males for this sort of mobility is the most noteworthy. The effect of educational attainment is regular across countries of residence: the odds-ratios of having experienced a change of residence in the period considered increases with the academic level, for any distance. The fact of being a house owner diminishes the likelihood of having migrated in all selected countries and this influence is relatively higher for inter-major administrative unit migration. Marital status and employment status have a less homogeneous behaviour as we compare across countries of settlement. Single people are more likely to move in Italy as we study changes in major administrative units, but the importance of the separated and divorced people is outstanding in the rest of the countries. In fact, as we refer to short distance this is the group more prone to migrate. In general, unemployed have migrated more than employed people at long distances, but this relationship differs by country of residence as we focus on the short distance migration. We have to take into account that short-distance mobility is more associated to the housing market, whilst long-distance responds more often to other motivations, such as job searching.

The new 2010-2011 census data will allow us to study new possibilities that have to do with the augmentation of the census samples for the immigrant population, thus permitting a more detailed geographical disaggregation of the data by origins and to pose other substantive questions, such as: how have the processes of geographical assimilation evolved after more than a decade of permanence of the immigration? and, finally, what will be the predictable impact of the present economic crisis on the internal migration patterns of native and non-native populations in the South of Europe? 


\section{References}

AJA, E.; ARANGO, J. (Eds). (2006). Veinte años de inmigración en España. Barcelona: CIDOB.

ARANGO, J. (2000). "Becoming a Country of Immigration at the End of the Twentieth Century: the Case of Spain". KING, R.; LAZARIDIS, G.; TSARDANIDIS, C. (Eds). Eldorado or Fortress? Migration in Southern Europe. London: Macmillan, pp. 253-276.

ARBACI, S.; MALHEIROS, J. (2010). "De-Segregation, Peripheralisation and the Social Exclusion of Immigrants: Southern European Cities in the 1990s". Journal of Ethnic and Migration Studies, 36 (2), pp. 227-255.

AUDENINO, P.; TIRABASSI, M. (2008). Migrazioni italiane. Storia e storie dall'Ancien re'gime a oggi. Milan: Bruno Mondadori.

BALDWIN-EDWARDS, M.; ARANGO, J. (1999). Immigrants and the Informal Economy in Southern Europe. London: Frank Cass.

BARTEL, A. P. (1989). "Where do the new U.S. immigrants live?". Journal of Labor Economics, 7 (4), pp. 371-91.

BARTEL, A. P.; KOCH, M. J. (1991). "Internal Migration of US Immigrants". ABOWD, J. M.; FREEMAN, R.B. (Eds.) Immigration, Trade, and the Labor Market. Chicago: The University of Chicago Press, pp. 121-134.

BELL, M.; MUHIDIN, S. (2009). "Cross-National Comparisons of Internal Migration". Human Development Research Paper 2009/30. United Nations Development Programme Human Development Reports Research Paper.

BELL, M.; REES, P. (2006). "Comparing migration in Britain and Australia: harmonisation through use of age-time plans". Environment and Planning A, 38 (5), pp. 959-988.

BELL, M.; BLAKE M.; BOYLE, P.; DUKE-WILLIAMS, O.; REES, P.; STILLWELL, J.; HUGO, G. (2002). "Cross-national comparison of internal migration: issues and measures". Journal of the Royal Statistical Society A, 165 (3), pp. 435-464.

BEVILACQUA, P.; De CLEMENTI, A.; FRANZINA, E. (Eds) (2002). Storia dell'emigrazione italiana. Partenze/Roma: Donzelli.

BILSBORROW, R. E. (1993). "Issues in the Measurement of Female Migration in Developing Countries". United Nations Internal Migration of Women in Developing Countries. New York: United Nations, pp. 116-130.

CANGIANO, A. (2008). "Foreign migrants in southern European countries: evaluation of recent data". I. J. RAYMER; F. WILLEKENS (Eds). International Migration in Europe: Data, Models and Estimates. Chichester: Wiley and Sons, pp. 89-114.

CARELlA, M.; PACE, R. (2001). "Some Migration Dynamics Specific to Southern Europe: South-North and East-West Axis". International Migration, 39 (4), pp. 63-99.

CHANT, S. (1992) (Ed.). Gender and Migration in Developing Countries. Londres: Belhaven Press.

CORGEAU, D. (1973a). “Migrants et migrations”. Population, 28 (1), pp. 95-129. 
CORKILL, D. (2001). "Economic migrants and the labour market in Spain and Portugal". Ethnic and Racial Studies, 24 (5), pp. 828-844

COURGEAU, D. (1973b). "Migrations et découpages du territoire". Population, 28 (3), pp. 511-538.

DE MIGUEL, V.; SOLANA, M.; PASCUAL, À. (2007). Las redes de Apoyo: el tejido social básico para la acomodación de los extranjeros. Madrid: Fundación BBVA.

DOMINGO, A. (2002). "Reflexiones demográficas sobre la inmigración internacional en los países del sur de la unión europea". Papers de Demografia, 215. Bellaterra: Centre d'Estudis Demogràfics.

DOMINGO, A.; GIL-ALONSO, F. (2007). "Immigration and Changing Labour Force Structure in the Southern European Union”. Population (English edition), 62 (4), pp. 709 727.

DOMINGO, A.; RECAÑO, J. (2010). "La inflexión del ciclo migratorio internacional en España: impacto y consecuencias demográficas”. AJA, E.; ARANGO, J.; OLIVER, J. (Eds). La inmigración en tiempos de crisis. Anuario de la Inmigración en España. Barcelona: Fundació CIDOB.

FINNEY, N.; SIMPSON, L. (2008). "Internal migration and ethnic groups: evidence for Britain from the 2001 Census". Population, Space and Place, 14, pp. 63-83.

FREY, W.H. (1995). "Immigration and internal migration "flight" from U.S. metropolitan areas: toward a new demographic balkanisation”. Urban Studies, 32 (4-5), pp. 733-757.

GARCÍA-COLL, A.; STILLWELL, J. (1999). "Inter-provincial migration in Spain: Temporal trends and age-specific patterns". International Journal of Population Geography, 5 (2), pp. 97-115.

GURAK, D. T.; KRITZ, M. M. (2000). “The interstate migration of U.S. immigrants: individual and contextual determinants". Social Forces, 78, pp. 1017-1039.

HUGO, G.J. (1993). "Migrant Women in Developing Countries. In United Nations". Internal Migration of Women in Developing Countries. New York: United Nations, pp. 4773

IOSIFIDES, T.; KING, R. (1996). "Recent immigration to Southern Europe: The socio-economic and labour market contexts". Journal of Area Studies, 4 (9), pp. 70-94

KING, R. (2000). "Southern Europe in the changing global map of migration". KING, R. et al. (Eds). Eldorado or Fortress? Migration in Southern Europe. London: Macmillan, pp. $1-26$.

KING, R.; ZONTINI, E. (2000). "The role of gender in the South European immigration model”. Papers. Revista de Sociologia, 60, pp. 35-52.

KING, R., FIELDING, A.; BLACK, R. (1997). "The International Migration Turnaround in Southern Europe". KING, R.; BLACK R. (Eds). Southern Europe and the New Immigrants. Portland: Sussex Academic Press, pp. 1-25.

KRAHN, H.; DERWING, T.M. (2005). "The Retention of Newcomers in Second and Third-Tier Canadian Cities”. International Migration Review, 39 (4), pp. 872-894.

KRITZ, M. M.; GURAK, D. T. (2001). "The impact of immigration on the internal migration of natives and immigrants". Demography, 38 (1), pp. 133-145. 
KRITZ, M. M.; NOGLE, J. M. (1994). "Nativity Concentration and Internal Migration among the Foreign-Born”. Demography, 31 (3), pp. 509-524.

LIAW, K.L.; FREY, W.H. (1998). "Destination choices of the 1985-90 young adult immigrants to the United States: importance of race, educational attainment, and labour market forces". International Journal of Population Geography, 4 (1), pp. 49-61.

LONG, J.F.; BOERTLEIN, C.G. (1990). "Comparing migration measures having different intervals". Current Population Reports, Series P-23, pp. 1-11. Washington DC: US Bureau of the Census.

MALHEIROS, J. (2002). "Ethni-cities: residential patterns in Northern European and Mediterranean Metropolises - implications for policy design”. International Journal of Population Geography, 8 (2), pp. 89-106.

MINNESOTA POPULATION CENTER (2009). Integrated Public Use Microdata Series International: Version 5.0. Minneapolis: University of Minnesota.

MOCETTI, S., PORELLO, C. (2010). "How does immigration affect native internal mobility? New evidence from Italy". Regional Science and Urban Economics, 40, pp. 427439.

MÓDENES, J.A. (Ed.) (2002). Trabajo y residencia como factores de las migraciones internas: un estudio comparativo europeo. Bellaterra: Centre d'Estudis Demogràfics.

MUÑOZ-PÉREZ, F.; IZQUIERDO, A. (1989). “L'Espagne, pays d'immigration”. Population, 44 (2), pp. 157-289.

NEWBOLD, K. B. (1996). "Internal migration of the foreign-born in Canada". International Migration Review, 30 (3), pp. 728-47.

NOGLE, J. M. (1994). "Internal migration for recent immigrants to Canada". International Migration Review, 28 (1), pp. 31-48.

PEIXOTO, J. (2002). "Strong market, weak state: the case of recent foreign immigration in Portugal". Journal of Ethnic and Migration Studies, 28 (3), pp. 483-497.

RECAÑO J.; ROIG, M. (2006). "The internal mobility of foreigners in Spain". Paper presented to the 2006 EAPS Conference, Liverpool, June 2006.

RECAÑO, J. (2003). "La movilidad geográfica de la población extranjera en España: un fenómeno emergente". Cuadernos de Geografía, 72, pp. 135-156.

RECAÑO, J.; DOMINGO, A. (2006). "Evolución de la distribución territorial y la movilidad geográfica de la población extranjera en España”. AJA, E.; ARANGO, J.; OLIVER J. (Eds). Veinte años de inmigración en España. Barcelona: Fundación CIDOB.

REES, P.; KUPISZEWSKI, M. (1999). Internal Migration and Regional Population Dynamics in Europe:a Synthesis. Strasbourg: Council of Europe Publishing.

RIBAS-MATEOS, N. (2004). "How can we understand immigration in Southern Europe?”. Journal of Ethnic and Migration Studies, 30 (6), pp. 1045-1063.

ROGERS, A.; HENNING, S. (1999). "The internal migration patterns of the foreign-born and native-born populations in the United States: 1975-80 and 1985-90". International Migration Review, 33 (2), pp. 403-29.

ROGERS, A.; WILLEKENS, F. J. (1986) (Eds). Migration and Settlement: a multiregional comparative study. Boston: Reydel. 
Joaquin RECAÑO; Verónica DE MIGUEL.- The internal migration of foreign-born population in...

SINGELMANN, J. (1993). "Levels and Trends of Female Internal Migration in Developing Countries: 1960-1980". United Nations Internal Migration of Women in Developing Countries. New York: United Nations, pp. 77-115.

SOLÉ, C. (2004). "Immigration policies in Southern Europe". Journal of Ethnic and Migration Studies, 30 (6), pp. 1209-122,

UNITED NATIONS (1993). Internal Migration of Women in Developing Countries. New York: United Nations. 